Volume 3 Nomor 2, Agustus 2018, halaman 151-158

\title{
PERBANDINGAN KEMAMPUAN KOMUNIKASI MATEMATIS SISWA ANTARA YANG MENGGUNAKAN METODE PEMBELAJARAN TALKING STICK DAN THINK TALK WRITE
}

\section{COMPARISON OF MATHEMATICAL COMMUNICATION ABILITY BETWEEN STUDENTS WHO USED THE LEARNING METHODS OF TALKING STICK AND THINK TALK WRITE}

\author{
Riska Dwi Handayani, Nandang, Wiwit Damayanti Lestari \\ Universitas Wiralodra, Jl. Ir. H. Djuanda KM.3 Indramayu 45213, \\ handayaniriskadwi@gmail.com,nndg1967@yahoo.com, \\ wiwitdamayantilestari@unwir.ac.id
}

\begin{abstract}
ABSTRAK
Tujuan penelitian ini adalah: (1) Untuk mengetahui kemampuan komunikasi matematis siswa yang pembelajarannya menggunakan metode Talking Stick dan metode Think Talk Write; (2) Untuk mengetahui kemampuan komunikasi matematis siswa yang lebih baik antara yang pembelajarannya menggunakan metode Talking Stick dengan metode Think Talk Write. Populasi dalam penelitian ini adalah seluruh kemampuan komunikasi matematis siswa kelas VIIISMP N 4 Sindang Tahun Pelajaran 2017/2018. Sampel penelitian ini diambil dengan menggunakan teknik cluster random sampling. Terpilih kelas VIII B sebagai kelas eksperimen 1 yang menggunakan metode pembelajaran Talking Stickdan kelas VIII A sebagai kelas eksperimen 2 yang menggunakan metode pembelajaranThink Talk Write. Instrumen dalam penelitian ini adalah soal uraian untuk mengukur kemampuan komunikasi matematis siswa. Dalam penelitian ini, untuk menganalisis data digunakan uji-t. Berdasarkan pengolahan data diperoleh bahwa kemampuan komunikasi matematis siswa yang pembelajarannya menggunakan metode Talking Stick lebih baik daripada yang menggunakan metode Think Talk Write. Hasil penelitian menunjukkan bahwa kemampuan komunikasi matematis siswa yang menggunakan metode pembelajaran Talking Stick lebih baik daripada yang menggunakan metode Think Talk Write. Dengan demikian, metode pembelajaran Talking Stick dapat diterapkan oleh guru sebagai alternatif dalam pembelajaran matematika untuk meningkatkan kemampuan komunikasi matematis siswa.
\end{abstract}

Kata Kunci : Komunikasi Matematis, Metode Talking Stick, Metode Think Talk Write

\begin{abstract}
The purpose of this research is:(1) To know the mathematical communication skills students who study by using the method of Talking Stick and the method ofThink Talk Write;(2)To know the mathematical communication skills better students among the analytical study using the method ofTalking Stick with the method of Think Talk Write. The population in this research are mathematical communication skills throughout of grade VIII SMP N 4 Sindang Year Academic2017/2018. This research sample taken using a technique Cluster Random Sampling. Choosing class of VIII B as a class experiment 1 which use learning method ofTalking Stick and class of VIII A as a class experiment 2 which use learning methodof Think Talking Write. Instruments in this research is a matter of explanation to measure the mathematical communication skills of students. In this research, to analyze data used test-t. Based on the processing of data was resulted that the mathematical communication skills students who study by
\end{abstract}


using method of Talking Stick it better than using method of Think Talk Write. The results showed that mathematical communication skills students use learning method of Talking Stick better than using the method ofThink Talk Write, Thus, learning method of Talking Stick can be applied by teachers as an alternative in studying of Mathematics to improve Mathematical Communication Skills of students.

Keyword: Mathematical Communication, Methods of Talking Stick, Methods of Think Talk Write

How to Cite: Handayani, R. D., Nandang, \& Lestari, W. D. (2018). Perbandingan Kemampuan Komunikasi Matematis Siswa Antara yang Menggunakan Metode Pembelajaran Talking Stick dan Think Talk Write. Mathline: Jurnal Matematika dan Pendidikan Matematika, Vol.3, No.2, 151-158.

\section{PENDAHULUAN}

Matematika merupakan salah satu mata pelajaran yang memiliki peranan penting dalam pendidikan. Hal ini dapat dilihat dengan ditetapkannya matematika sebagai salah satu mata pelajaran pokok/wajib dalam Ujian Nasional (UN) serta dilihat dari jumlah jam mata pelajaran matematika yang lebih banyak (Fitri, dkk., 2014). Oleh karena itu, matematika adalah salah satu ilmu pengetahuan yang sangat penting yang harus dikuasai perserta didik di sekolah sebagai bekal dalam kehidupan bermasyarakat. Namun pada kenyataannya, mata pelajaran matematika terkenal sebagai mata pelajaran yang sulit, di mata siswa pelajaran matematika itu seperti musuh yang menakutkan, mereka selalu beranggapan bahwa matematika itu identik dengan nilai yang jelek (Setiyaningrum \& Istiqomah, 2015).

National Council of Teachers of Mathematics menetapkan lima standar kemampuan matematis, yaitu kemampuan pemecahan masalah (problem solving), kemampuan komunikasi (communication), kemampuan koneksi (connection), kemampuan penalaran (reasoning), dan kemampaun representasi (representation) merupakan kemampuan yang penting untuk dikembangkan dan harus dimiliki oleh siswa (Adharani, 2012). Menurut The Intented Learning Outcomes bahwa komunikasi matematis merupakan kemampuan mengkomunikasikan ide-ide matematika secara koheren kepada teman, guru, dan lainnya melalui bahasa lisan maupun tulisan (Ramellan, dkk., 2012). Hal ini, berarti dengan adanya komunikasi matematis guru dapat memahami kemampuan komunikasi matematis siswa dalam mengkomunikasikan pemahamannya.

Namun, faktanya banyak siswa yang mengalami kesulitan dalam mengkomunikasikan kepada siswa lain. Seolah-olah siswa tersebut tidak mau berbagi dengan siswa lainnya. Hal ini, sesuai dari observasi di lapangan yang dilakukan oleh 
Wihatma (Harahap, dkk., 2012) menyatakan bahwa kemampuan siswa dalam berkomunikasi dan mengkomunikasikan ide-ide matematis ternyata masih kurang sekali. Oleh karena itu, kemampuan komunikasi matematis penting dimiliki bagi setiap siswa.

Metode Talking Stick merupakan pembelajaran yang mendorong peserta didik untuk berani mengemukakan pendapat dan menggunakan tongkat sebagai alat petunjuk giliran (Suprijono, 2015). Metode ini bermanfaat karena mampu menguji kesiapan siswa, melatih keterampilan mereka dalam membaca dan memahami materi pelajaran dengan cepat, dan mengajak mereka untuk terus siap dalam situasi apapun.

Metode Think Talk Write adalah strategi yang memfasilitasi latihan berbahasa lisan dan menulis bahasa tersebut dengan lancar (Huda, 2013). Pada metode ini siswa aktif dalam berpikir, berbicara dan menulis ketika berlangsungnya belajar mengajar di kelas.

Tujuan penelitian ini adalah (1) Untuk mengetahui kemampuan komunikasi matematis siswa yang pembelajarannya menggunakan metode Talking Stick dan metode Think Talk Write; (2) Untuk mengetahui kemampuan komunikasi matematis siswa yang lebih baik antara yang pembelajarannya menggunakan metode Talking Stick dengan metode Think Talk Write.

\section{METODE PENELITIAN}

Metode penelitian yang digunakan adalah metode penelitian eksperimen. Pada penelitian ini penulis membagi sampel menjadi dua yaitu kelas eksperimen I dan kelas eksperimen II. Kelas eksperimen I adalah kelas yang pembelajarannya menggunakan metode Talking Stick sedangkan kelas eksperimen II adalah kelas yang pembelajarannya menggunakan metode Think Talk Write.

Populasi dalam penelitian ini adalah seluruh kemampuan komunikasi matematis kelas VIII SMP N 4 Sindang sebanyak 8 kelas yang berjumlah 325 siswa. Teknik pengambilan sampel pada penelitian ini menggunakan teknik cluster random sampling yaitu teknik pengambilan sampel yang dilakukan secara acak. Dalam penelitian ini dari 8 kelas diambil 2 kelas, diperoleh kelas VIII-B sebagai kelas eksperimen I dan kelas VIII-A sebagai kelas eksprimen II. Instrumen yang digunakan untuk mengukur kemampuan komunikasi matematis digunakan tes kemampuan komunikasi matematis yang diberikan dalam bentuk tes uraian (essay).

Teknik analisis data yang digunakan meliputi Uji Normalitas, Uji Homogenitas Dua Varians, Uji Kesamaan Dua Rata-rata (Uji-t), Uji-t' serta Uji U-Mann Whitney. Analisis yang dilakukan, menggunakan bantuan Microsoft Office excel 2010. Selanjutnya 
kriteria pengujian hipotesis mengikuti aturan jika nilai $t_{\text {hitung }}>t_{\text {tabel }}$ maka Tolak Ho Sebaliknya jikajika nilait $t_{\text {hitung }} \leq t_{\text {tabel }}$ makaTerima Ho.

\section{HASIL DAN PEMBAHASAN}

Banyak siswa yang belum memahami arti pentingnya matematika dan tidak tahu tujuan belajar matematika. Akibatnya matematika menjadi kurang diminati dan dianggap pelajaran yang sulit. Sehingga banyak ditemukan dalam pembelajaran matematika, siswa mudah lupa, tidak tahu memulai dari mana dalam menyelesaikan soal atau bahkan sulit memahami materi. Selain itu, faktor lain yang membuat siswa kurang meminati belajar matematika yaitu dalam proses pembelajaran dimana siswa yang pasif dan tidak adanya sesuatu yang dapat membuat siswa merasa senang dalam belajar matematika. Karena hal tersebut kemampuan komunikasi matematis siswa kurang baik.

Kemampuan komunikasi matematis adalah kemampuan menyampaikan gagasan/ide matematis, baik secara lisan maupun tulisan serta kemampuan memahami dan menerima gagasan/ide matematis orang lain secara cermat, analitis, kritis, dan evaluatif untuk mempertajam pemahaman (Lestari \& Yudhanegara, 2015). Proses pembelajaran matematika dapat berjalan dengan baik apabila siswa mampu memahami materi yang diajarkan oleh guru dan dapat mengkomunikasikannya dengan siswa lain, kemampuan inilah yang dinamakan kemampuan komunikasi. Untuk dapat lebih meningkatkan kemampuan komunikasi matematis, dapat dilakukan dengan menggunakan metode pembelajaran yang tepat.

Metode Talking Stick adalah metode pembelajaran tongkat berbicara. Teknik ini diberi nama tongkat berbicara, karena pada saat tongkat itu berhenti ke salah satu kelompok, maka kelompok yang mendapat tongkat tersebut harus menjawab pertanyaan yang diberi oleh guru. Tidak ada kendala atau masalah yang terjadi dalam berlangsungnya belajar mengajar di kelas. Oleh karena itu, metodeinisangat baik digunakan untuk mengajarkan informasi-informasi awal guna mempelajarimateri selanjutnya. Sehinggapada pembelajaran yang menggunakan metodeTalking Stick dapat terjadi pemerataan informasi atau topik yang diketahui oleh siswa.

Metode Think Talk Write adalah strategi pembelajaran yang pada dibangun melalui berpikir, berbicara dan menulis. Selain itu siswa bekerja dengan sesama siswadalam suasana gotong-royong dan mempunyai banyak kesempatan untuk mengolah informasi dan meningkatkan ketermapilan berkomunikasi (Yamin \& Ansari, 2008). Keunggulandari 
teknik pengajaran Think Talk Writeadalah adanya struktur yang jelas dan memungkinkan siswa untuk berbagi dengan kelompok yang berbedadengan singkat dan teratur.

Setelah dilakukan pengolahan data, diperoleh gambaran kemampuan komunikasi matematis siswa antara yang menggunakan metode pembelajaran Talking Stick dengan Think Talk Write, seperti pada tabel di bawah ini:

Tabel 1. Data Skor Tertinggi dan Terendah

\begin{tabular}{ccc}
\hline Skor & Kelas Eksperimen I & Kelas Eksperimen II \\
\hline Tertinggi & 95 & 95 \\
Terendah & 60 & 45 \\
Ideal & 100 & 100 \\
\hline
\end{tabular}

Berdasarkan tabel di atas menunjukkan bahwa hasil tes akhir kelas eksperimen I yang pembelajarannya menggunakan metode Talking Stick diperoleh skor tertinggi 95 dan skor terendah 60 dengan skor ideal 100, sedangkan hasil tes akhir kelas eksperimen II yang pembelajarannya menggunakan metode Think Talk Write diperoleh skor tertinggi 95 dan skor terendah 45 dengan skor ideal 100.

Setelah dilakukan pengolahan data diperoleh skor rata-rata, varians dan simpangan baku dari kelas eksperimen I dan kelas eksperimen II yang dapat dilihat pada tabel di bawah ini:

Tabel 2. Data Hasil Tes Akhir

\begin{tabular}{ccc}
\hline Nilai & Kelas Eksperimen I & Kelas Eksperimen II \\
\hline Jumlahsiswa $(n)$ & 36 & 36 \\
Rata-rata $(\bar{x})$ & 76,61 & 66,75 \\
Varians $\left(s^{2}\right)$ & 86,64 & 192,02 \\
Simpangan Baku $(s)$ & 9,308 & 13,857 \\
\hline
\end{tabular}

Berdasarkan tabel di atas, diperoleh bahwa kemampuan komunikasi matematis siswa yang menggunakan metode pembelajaran Talking Stick pada kelas eksperimen I memperoleh rata-rata 76,61, varians 86,64 dan simpangan baku 9,308. Sedangkan kemampuan komunikasi matematis siswa yang menggunakan metode pembelajaran Think Talk Write pada kelas eksperimen II memperoleh rata-rata 66,75, varians 192,02, dan simpangan baku 13,857. 
Setelah diperoleh rata-rata, varians dan standar deviasi, langkah selanjutnya menguji normalitas dan homogenitas data tes akhir kelas eksperimen I dan kelas eksperimen II.

Tabel 3. Data Uji Normalitas

\begin{tabular}{cccc}
\hline Kelas & $\chi_{\text {hitung }}^{2}$ & $\chi_{\text {tabel }}^{2}$ & Keterangan \\
\hline Eksperimen I & 8,09 & 9,49 & Normal \\
Eksperimen II & 8,08 & 9,49 & Normal \\
\hline
\end{tabular}

Berdasarkan tabel di atas, menunjukkan bahwa pada kelas eksperimen I diperoleh $\chi_{\text {hitung }}^{2}=8,09$ dan $d k_{\text {eksperimen } 1}=k-1=6-1=5, \chi_{(0,055)}^{2}=9,49$. Karena $\chi_{\text {hitung }}^{2}<\chi_{(0,05 ; 5)}^{2}$, maka $\mathrm{H}_{0}$ diterima. Artinya data berdistribusi normal. Sedangkan kelas eksperimen II diperoleh $\chi_{\text {hitung }}^{2}=8,08$ dan $\quad d k_{\text {eksperimen } 2}=k-1=5-1=4, \chi_{(0,05: 4)}^{2}=9,49$. Karena $\chi_{\text {hitung }}^{2}<\chi_{(0,05 ; 4)}^{2}$, maka $\mathrm{H}_{0}$ diterima. Artinya data berdistribusi normal.

Setelah data tes akhir kelas eksperimen I dan kelas eksperimen II berdistribusi normal, dilanjutkan dengan uji homogenitas dua varians. Uji homogennitas menggunakan varians kelas eksperimen I dan varians kelas eksperimen II.

Tabel 4. Data Uji Homogenitas Dua Varians

\begin{tabular}{cccccc}
\hline Kelas & $\mathbf{N}$ & Varians & $F_{\text {hitung }}$ & $F_{\text {tabel }}$ & Keterangan \\
\hline Eksperimen I & 36 & 86,64 & \multirow{2}{*}{0,451} & 1,73 & Homogen \\
Eksperimen II & 36 & 192,02 & & & \\
\hline
\end{tabular}

Berdasarkan data di atas dengan taraf signifikan $\alpha=0,05$ dan $\mathrm{dk}_{1}=35$ dan $\mathrm{dk}_{2}=$ 35, diperoleh $F_{\text {hitung }}=0,451$ dan $F_{\text {tabel }}=1,73$. Berdasarkan kriteria hasil uji homogenitas dapat disimpulkan bahwa $\mathrm{F}_{\text {hitung }}<\mathrm{F}_{\text {tabel }}$ maka data tes akhir kelas ekskperimen I dan kelas eksperimen II bersifat homogen.

Berdasarkan perhitungan uji normalitas dan homogenitas terhadap data tes akhir, diperoleh data tes akhir kelas eksperimen I dan kelas eksperimen II berdistribusi normal dan bersifat homogen, maka selanjutnya dilakukan uji kesamaan dua rata-rata yaitu menggunakan uji-t. 
Tabel 5. Data Uji Kesamaan Dua Rata-rata

\begin{tabular}{cccccc}
\hline Kelas & Rata-rata & Varians & $S_{\text {gab }}^{2}$ & $t_{\text {hitung }}$ & $t_{\text {tabel }}$ \\
\hline Eksperimen I & 76,61 & 86,64 & & & \\
Eksperimen II & 66,75 & 192,02 & 100,665 & 3,54 & 1,67 \\
\hline
\end{tabular}

Berdasarkan tabel di atas, dengan taraf signifikan $\alpha=0,05$ dan derajat kebebasan $(\mathrm{dk})=\mathrm{n}_{1}+\mathrm{n}_{2}-2=36+36-2=70$ diperoleh $\mathrm{t}_{\text {hitung }}=3,54$ dan $\mathrm{t}_{\text {tabel }}=1,67$, dapat disimpulkan bahwa $t_{\text {hitung }}>t_{\text {tabel }}$. Karena $t_{\text {hitung }}>t_{\text {tabel }}$, maka $\mathrm{H}_{0}$ ditolak, artinya kemampuan komunikasi matematis siswa yang pembelajarannya menggunakan metode Talking Stick lebih baik daripada yang menggunakan metode Think Talk Write.

\section{KESIMPULAN}

Berdasarkan analisis yang dilakukan, diperoleh bahwa kemampuan komunikasi matematis siswa yang menggunakan metode pembelajaran Talking Stick pada kelas eksperimen I memperoleh rata-rata 76,61, sedangkan kemampuan komunikasi matematis siswa yang menggunakan metode pembelajaran Think Talk Write pada kelas eksperimen II memperoleh rata-rata 66,75. Apabila ditinjau secara keseluruhan, kemampuan komunikasi matematis siswa yang memperoleh pembelajaran matematika menggunakan metode Talking Stick lebih baik daripada yang menggunakan metode Think Talk Write.

Adapun saran untuk penerapan pembelajaran matematika melalui metode pembelajaran Talking Stick, dapat menindaklanjuti hasil penelitian ini dengan pokok bahasan yang lebih luas dan pada jenjang pendidikan yang berbeda. Untuk kemampuan matematika lainnya seprti penalaran matematis, koneksi matematis dan kemampuankemampuan matematis lainnya sehingga diperoleh suatu kesimpulan yang menyeluruh.

\section{DAFTAR PUSTAKA}

Adharani, L. A. (2012). Pembelajaran Matematika dengan Metode Penemuan Terbimbing untuk Meningkatkan Kemampuan Representasi dan Pemecahan Pemecahan Masalah Matematis Siswa SMP. Jurnal Penelitian Pendidikan, Vol. 12, No. 2, 110.

Fitri, R., Helma \& Syarifuddin, H. (2014). Penerapan Strategi The Firing Line pada Pembelajaran Matematika Siswa kelas XI IPS SMA Negeri 1 BATIPUH. Jurnal Pendidikan Matematika, Vol.3 No. 1, 18-22.

Harahap, R., Dewi, I., \& Sumarmo. (2012). Perbedaan Peningkatan Kemampuan Komunikasi dan Koneksi Matematis Siswa Melalui Pembelajaran Kontekstual dengan Kooperatif tipe STAD di SMP Al-Wasliyah 8 Medan. Jurnal Pendidikan Matematika PARADIKMA, Vol. 5 No. 2, Hal: 186-204. 
158 Perbandingan Kemampuan Komunikasi Matematis Siswa Antara yang Menggunakan Metode Pembelajaran Talking Stick dan Think Talk Write

Huda, M. (2013). Model-model Pembelajaran dan Pengajaran. Yogyakarta: Pustaka Belajar.

Lestari, K. E., \& Yudhanegara, M. R. (2015). Penelitian Pendidikan Matematika. Bandung: PT. Refika Aditama.

Ramellan, P., Edwin Musdi, E., \& Armiati. (2012). Kemampuan Komunikasi Matematis dan Pembelajaran Interaktif. Jurnal Pendidikan Matematika, Part.2 Vol. No.1, 7782.

Setyaningrum, E., \& Istiqomah. (2015). Efektifitas Penerapan Model Pembelajaran Think Talk Write Terhadap Proses Belajar Matematika Siswa Kelas VII SMP SMP Negeri 3 Magelang. Jurnal Pendidikan Matematika, Vol. 1 No. 2, 30-42.

Suprijono, A. (2015). Cooperatif Learning (teori dan Aplikasi Paikem). Yogyakarta: Pustaka Belajar.

Yamin, M., \& Ansari, B. (2008). Taktik Mengembangkan Individu Siswa. Jakarta: Rosemata Sampurna. 